Paweł Kosowski, https:/ / orcid.org/0000-0002-6552-2729

Faculty of Pedagogy and Psychology

Department of Psychology

Jan Kochanowski University in Kielce

\title{
Relationships between forgiveness, life satisfaction, and empathy in honorary blood donors. The mediating role of forgiveness
}

\author{
Relacje przebaczenia, satysfakcji z życia oraz empatii u honorowych \\ krwiodawców. Mediacyjna rola przebaczenia ${ }^{1}$
}

https:/ / doi.org/10.34766/ fetr.v48i4.879

\begin{abstract}
Numerous studies have shown that voluntary blood donation can be considered as prosocial behavior, resulting from empathetic motives and a desire to help people in need of transfusion of whole blood or blood components. The process of donation is carried out according to the prescribed stages, which include the initial donor qualification and blood testing, and exclusion of any diseases or postoperative complications that may have negative consequences for the future recipient. In light of the current trend in psychological research in the group of blood donors, we decided to examine the potentially coexisting factors and factors likely to enhance empathy in this group, that is the disposition to forgive and satisfaction with life.The main aim of the present study was to examine the relationship between life satisfaction, disposition to forgive, and the empathy quotient, the degree to which life satisfaction and forgiveness can explain empathy, as well as the mediating role of forgiveness between life satisfaction and empathy in a group of honorary blood donors. The sample included 111 individuals (72 women and 39 men). The mean age of the respondents was 24.9 years $(\mathrm{SD}=8.7)$. The study variables were measured using the SWLS, HFS and SSIE scales. The results of the conducted study showed associations between forgiveness and empathy and life satisfaction, and a satisfactory level of explaining empathy by forgiveness (with a higher proportion of positive forgiveness) and life satisfaction. Mediation analysis also showed that forgiveness indirectly explains the relationship between life satisfaction and empathy. Correlations between term of blood donation and life satisfaction and between general and negative forgiveness was also found to be significant. The results of the conducted study can be considered as a contribution to further, more extensive research in the group of honorary blood donors. The results were confirmed in the literature, indicating a strong relationship between forgiveness and empathy, which may constitute a basis for the conclusion that forgiveness and life satisfaction resulting from a longer term of donating blood may enhance the level of empathy, as well as empathy itself may improve the level of forgiveness and life satisfaction.
\end{abstract}

Keywords: voluntary blood donation, satisfaction with life, forgiveness, empathy, mediation

Abstrakt: Honorowe krwiodawstwo uznać można za wyraz zachowania prospołecznego,
wynikającego z pobudek empatycznych oraz chęci pomocy osobom wymagającym przetoczenia krwi
pełnej lub jej poszczególnych składników- wskazują na to liczne badania. Proces donacji przebiega
zgodnie z przewidzianymi etapami zakładającymi wstępną kwalifikację oraz badanie krwi oraz
wykluczenie ewentualnych chorób lub powikłań pozabiegowych, które mogą nieść negatywne

${ }^{1}$ Artykuł w języku polskim dostępny jest na stronie:

https://www.stowarzyszeniefidesetratio.pl/Presentations0/2021-4Koso2.pdf 
konsekwencje dla przyszłego biorcy. W związku z obecnym w psychologii trendem badań w grupie honorowych krwiodawców, podjęto się sprawdzenia czynników, które mogą wspólistnieć jak również wzmacniać empatię $\mathrm{w}$ tej grupie, czynniki te to dyspozycja do przebaczenia oraz satysfakcja z życia. Celem prezentowanego badania było sprawdzenie związku pomiędzy satysfakcją z życia, dyspozycją do przebaczenia oraz ilorazem empatii, poziom wyjaśniania empatii przez satysfakcję z życia i przebaczenie oraz mediacyjną rolę przebaczenia między satysfakcją z życia a empatią w grupie honorowych krwiodawców. Grupa badanych wyniosła 111 osób (72 kobiety i 39 mężczyzn). Średnia wieku osób badanych wyniosła 24.9 lat $(S D=8,7)$. Badane zmienne zostały zmierzone za pomocą skal: SWLS, HFS oraz SSIE. Rezultaty przeprowadzonego badania wykazały związki pomiędzy przebaczeniem a empatią i satysfakcją z życia, oraz zadowalający poziom wyjaśniania empatii przez przebaczenie (z większym udziałem przebaczenia pozytywnego) i satysfakcję z życia. Analiza mediacji wykazała również, że przebaczenie pośrednio wyjaśnia relację satysfakcji z życia i empatii. Istotna okazała się również korelacja stażu krwiodawstwa z poziomem satysfakcji z życia oraz przebaczenia ogólnego oraz negatywnego. Wyniki przeprowadzonego badania uznać można za przyczynek do dalszych, bardziej rozbudowanych badań $w$ obrębie grupy honorowych krwiodawców. Rezultaty znalazły potwierdzenie w literaturze przedmiotu, wskazując na silne relacje przebaczenia oraz empatii, co może stanowić podstawę do wnioskowania, że przebaczenie oraz satysfakcja z życia, wynikające z dłuższego stażu krwiodawstwa mogą wzmacniać poziom empatii, jak również sama empatia może wzmacniać poziom przebaczenia oraz satysfakcji z życia.

Słowa kluczowe: Honorowe krwiodawstwo, satysfakcja z życia, przebaczenie, empatia, mediacja

\section{Introduction}

In case of medical emergencies, such as injuries caused by traffic accidents, necessary surgery, or diseases of the hematopoietic system, the only way to save an individual's life is to transfuse blood or blood components (Higgins, 1994; Goette, Stutzer, 2020).

Historically, voluntary blood donation has been based on voluntary and unrewarded giving resulting from the prosocial motivation of donors (Slonim et al. 2014). Also, according to Titmuss's (1971) theorem, honorary blood donation has historically been promoted as pure altruism.

Masser et al. (2008) indicate that voluntary blood donation is a non-remunerated behavior that nevertheless involves more or fewer benefits or rewards. This is likely to result from the fact indicated by Davey (2004) and Gilcher and McCombs (2005) that newly developed medical techniques, whether types of cancer treatment or surgical procedures, require increasing amounts of available blood (Davey, 2004) and that many restrictions are placed on the eligibility criteria for potential donors, such as travelling to specific locations on the globe or donor medical history (Gilicher, McCombs, 2005). Increased blood demand and introduction of restrictions may, therefore, bring about the need to introduce small rewards for unpaid donations to motivate potential donors.

Blood donation process is not particularly complicated or advanced in terms of medical practice. Depending on a given method, i.e. conventional, plasmapheresis or apheresis, by inserting a special needle combined with a specialized device dedicated to a specific method for the collection of blood or blood components into a vein on the inside of 
an elbow, a specific number of milliliters of blood $(450 \mathrm{ml})$, plasma $(600 \mathrm{ml})$, platelets $(250$ $\mathrm{ml})$, red blood cells $(2 \times 300 \mathrm{ml})$ and white blood cells $(200 \mathrm{ml})$ is collected .

The blood donation procedure anticipates successful donation at the end of the path. It begins with registration of the donor who fills in a special health questionnaire to provide information about, illnesses passed through, any medications taken and general well-being, and in the case of women, information regarding pregnancy and menstruation. The next step in the donation process is blood collection to check the level of hemoglobin and hematocrit. This is followed by a medical assessment of blood pressure, pulse, and medical history, at which point the donor is qualified or disqualified to donate blood or blood components. The final stage is actual donation.

The psychology of honorary blood donation focuses on issues including prosocial and altruistic behavior (e.g. Gerraud, Tissot, 2016), and on the Theory of Planned Behaviour (Giles et al. 2004; Amponsah-Afuwape et al. 2002). A study that also seems to be of interest for the psychology of blood donation was conducted by Alfieri (2017) on a group of 285 adolescents to investigate the nature of motivations and representations related to blood donations in the future. The results of this study showed that adolescents (potential future donors) have no knowledge or are misinformed about the donation process, which may cause fear and reluctance to donate blood. The second part of the study, focusing on motivation, showed that there are differences between factors motivating boys and girls to donate in the future - for boys, the basic motivation with a positive impact was the social motivation, while the ego-protective motivation showed a negative impact. For girls, understanding proved to be the strongest motivating factor (Alfieri, 2017).

In the face of the -increasingly popular tendency to study voluntary blood donation in psychological terms, more and more interesting issues concerning psychological predispositions of donors become to emerge. The most widely investigated issue is the level of empathy and all factors likely to improve it. It can be assumed, that empathy is one of the most important factors influencing the willingness or need to share a certain amount of the life-giving substance with complete strangers in order to help them.

\section{Satisfaction with life and psychological well-being}

According to $\mathrm{WHO}$, a key component in achieving high-level health is having highquality life (Wysokiński et al., 2009). The quality of life is determined by the activity of the following three components: (1) subjective positive well-being, (2) absence of negative feelings, and (3) presence of positive feelings (Juczyński, 2001).

Subjective well-being can be defined as cognitive and emotional assessment of one's own life (Czapiński, 2004) by comparing one's actual situation with self-defined standards and self - defined goals (Wysokiński et al. 2009; Juczyński, 2001). The cognitive assessment 
of life satisfaction includes such components, as positive evaluation of relationships and contacts with other people, satisfaction with work and family relationships, etc. Emotional evaluation, on the other hand, includes such components, as the presence of more positive emotions and relative absence of negative emotions (Zimbardo et al., 2017).

Psychological well-being is directly related to the sense of happiness, which can be (after Argyle, 2004) defined as a kind of subjective satisfaction and occurrence of positive emotions at a certain time (Wolpiuk-Ochocińska, 2018).

Numerous studies have shown strong associations between life satisfaction and empathy. The study by Too et al. (2021) showed that empathy plays a significant role in promoting achievement of life satisfaction, while the study by Di Tella et al. (2020) showed that high levels of empathy are positively related to greater life satisfaction.

\section{a. Forgiveness}

Since becoming an issue of substantial academic interest in the last two decades of the twentieth century (Mróz, Kaleta, 2016), forgiveness, has been defined in a variety of ways (Zarzycka, 2016), thus emerging as a a multidimensional psychological construct encompassing philosophical, cultural, theological and psychological aspects (Brudek, Steuden, 2015).

According to McCullough and Worthington (1999), forgiveness can be considered according to two different approaches: a transcendental one, rooted in philosophy and theology aspects, understanding forgiveness as a deeply intimate and hardly perceptible behaviour, which is the basis of religious life, and a psycho-social one, which allows for empirical examination of the mechanisms of action and the relationship of forgiveness with other psychological variables (McCullough, Worthington, 1999; Brudek, Steuden, 2015).

The growing academic interest in forgiveness has resulted in a lack of agreement with regard to the meaning and mechanism of forgiveness between researchers. However, after reviewing positions of different research communities, it is possible to identify common claims defining specific aspects of forgiveness (Brudek, Steuden, 2015; Mróz, Kaleta 2016; Sells, Hargrave, 1998), which indicate that forgiveness in the general sense can be understood as a conscious decision of an individual to refrain from negative feelings, behaviours or thoughts directed toward the perpetrator of a harm (Exline et al., 2003).

Thompson defines forgiveness as the reformulation of the harm by transforming negative feelings directed at the perpetrator or the circumstances into neutral or positive ones (Thompson et al. 2005; Kaleta, Mróz, Guzewicz, 2016) and points to three different directions of forgiveness: [1]oneself, [2]others and [3] the situations, in two dimensionspositive and negative.

Further review of the literature (after Brudek, Steuden, 2015), allows to distinguish three categories of defining forgiveness (see Table 1): 
Table 1. Three categories of understanding of forgiveness in psychology

\begin{tabular}{|c|l|c|}
\hline $\begin{array}{c}\text { Understanding } \\
\text { category }\end{array}$ & \multicolumn{1}{|c|}{ Characteristics } & Authors \\
\hline Forgiveness & $\begin{array}{l}\text { The person's disposition to forgive recurring } \\
\text { offences present in interpersonal relationships } \\
\text { and situations is understood as overcoming } \\
\text { negative feelings toward th offender and } \\
\text { showing him/her kindness and forbearance. }\end{array}$ & Tripathi, Mullet,2010 \\
\hline Dyadic forgiveness & $\begin{array}{l}\text { The tendency to forgive the person who is in a } \\
\text { relationship with the subject (dyad). In this } \\
\text { model, the subject of forgiveness is the } \\
\text { transgressions that have occurred in the } \\
\text { relationship. Fincham, Hall, Beach, }\end{array}$ & 2005 \\
\hline Offence-specific & $\begin{array}{l}\text { Forgiveness of a specific transgression that } \\
\text { occurred in a specific interpersonal context. In } \\
\text { the context of forgiveness as a reaction to an } \\
\text { experienced wrong, the act of forgiveness is } \\
\text { identical with a change from negative to positive } \\
\text { feelings, which, among other things, may result } \\
\text { from the passage of time. }\end{array}$ & $\begin{array}{c}\text { Thomson, Snyder, } \\
\text { 2003; McCullough, } \\
\text { Pargament, Thoresen, } \\
\text { 2000 }\end{array}$ \\
\hline
\end{tabular}

Source: prepared based on Brudek and Steuden 2015.

In the presented study, forgiveness was approached according to the first category of understanding presented above.

Different research communities have reached a consensus agreed however to a common notion that forgiveness may or may not be accompanied by an increase in positive emotions and behaviours toward the perpetrator of the hurt or harm (e.g. Gottman, 2014).

In reference to the study presented herein, the literature indicates that forgiveness is an important explanatory factor for life satisfaction and empathy (Chung, Myong-Sun 2014). A study conducted by Ye et al. (2019) proved that there is a strong association between forgiveness (measured using the HFS scale used in the presented study) and the level of empathy. The relationship between these two variables was also investigated in neuropsychological research (Farrow et al. 2000) using functional magnetic resonance imaging, which showed that forgiveness and empathy tasks engage similar brain regions.

\section{b. Empathy}

Empathy is defined as the ability to understand and share emotions of other people (Pastwa-Wojciechowska, Piechowicz, Bidzan, 2015; Decety, Moriguchi, 2007). Singer and Lamm (2009) consider empathy as a multidimensional construct describing the ability to perceive, understand and feel the emotions manifested by others (Pastwa-Wojciechowska, Piechowicz, Bidzan, 2015), which involves emotional, cognitive and behavioural dimensions. 
Long-standing research on empathy gave rise to two main approaches to defining empathy: affective and cognitive, to be integrated by later studies (mentioned above). Researchers representing the affective approach understood empathy as a predisposition to react emotionally to experiences observed in others and identified three basic responses typical of empathy: [1] sensitivity to the feelings of others,[2] the ability to participate in the feelings of others, and [3] temporal identification with the state of others (Kazimierczak, 2004; Rembowski, 1989; Reykowski, 1992).Researchers representing the cognitive approach on the other hand, defined empathy as a kind of cognitive understanding of others largely in terms of sharing emotions of others based on understanding others' subjective perception of the environment (Mead, 1934 - after Davis, 1999).

Davis (1991) points out that empathy is a kind of spectrum of cognitive and affective processes that, in a person observing another person's situation, induce cognitive perspective-taking followed by affective and non-affective outcomes (Kazimierczak, 2008).

In reference to the presented study, the level of empathy seems to be an interesting indicator in the group of voluntary blood donors, for it may be assumed that this construct is likely to be found among reasons for voluntary blood donation. Also, the literature points to the relationship between empathy, life satisfaction and forgiveness (e.g. Chung, Myong-Sun 2014; Ye et al.2019), just like the study by Farrow et al. (2000).

\section{Aim and specific design of the study}

The aim of this study was to examine the relationship between the level of empathy and the disposition to forgive, and between the cognitive dimension of life satisfaction, and the term of blood donation and the volume of donated blood. It was assumed that voluntary blood donation is a manifestation - of emphatic understanding of the situation of people in need of transfusion of this life-giving substance. Therefore, the focus was placed on factors that may be important for the level of empathy and consequently, for blood donation.

To this end, the following research questions were formulated:

1. Are there any relationships between life satisfaction, disposition to forgive and level of empathy?

2. To what extent life satisfaction and the disposition to forgive explain empathy?

3. Does forgiveness mediate the relationship between life satisfaction and empathy?

4. Do the variables differ in the level of severity depending on gender?

5. Do the term of blood donations and volume of donated blood correlate with levels of life satisfaction, empathy and forgiveness?

The following research hypotheses were put forward:

H1: There are positive relationships between life satisfaction, forgiveness and empathy. 
H1a: Higher levels of life satisfaction will be associated with higher levels of empathy.

H1b: Higher levels of the disposition to forgive will be associated with higher levels of life satisfaction.

$\mathrm{H} 2$ : Life satisfaction and disposition to forgive will explain the level of empathy.

H2a: The positive dimension of forgiveness will to a larger extent explain the level of empathy in relation to the negative dimension.

H3: The disposition to forgive will have a mediating role in explaining empathy by life satisfaction.

H4: There are statistically significant gender differences in the study variables.

H5: Longer term of blood donation and higher volume of donated blood will be associated with higher levels of empathy and life satisfaction.

\section{a. The sample}

The study sample consisted of 111 participants - 39 men (35.1\%) and 72 women $(64.9 \%)$. The mean age in the study group was 29.4 years $(\mathrm{SD}=8.7)$. The minimum age was 18 years. In the study group, 58 individuals (52.3\%) completed university education, 52 (46.8\%) secondary education and one person $(0.9 \%)$ primary education. All study participants were honorary blood donors with different donation terms: 31 respondents $(27.9 \%)$ donating for at least 5 years, 17 respondents $(15.3 \%)$ for at least 10 years, $13(11.7 \%)$ for 15 years, 12 $(10.8 \%)$ for more than one year, 11 (9.9\%) for less than one year, 11 (9.9\%) for at least 4 years, $9(8.1 \%)$ for at least 2 years and 7 (6.3) for 3 years. In the study group, 59 participants (53.2\%) held one or more of the Distinguished Honorary Blood Donor decorations. We used purposive sampling technique, using special honorary blood donor groups in social networks . Participation in the study was voluntary and failed to entail any material benefits; additionally, the respondents were free to withdraw from the study at any time.

\subsection{Procedure and materials}

In the study, three scales were used: [1] short form of The Empathy Quotient (SSIE)(EQ-Short)(Wakabayashi et al., 2006) in the Polish adaptation of Jankowiak- Siuda et al. (2017), [2] Heartland Forgiveness Scale (HFS)(Thompson et al. 2005) in the Polish adaptation of Kaleta, Mróz and Guzewicz (2016), and [3] Satisfaction With Life Scale-SWL (Diener et al., 1985) in the Polish adaptation of Juczyński (2001).

[1] EQ-Short consists of 22 items. They are related to the recognition of thoughts or feelings of and affective reactions to other people (Jankowiak- Siuda et al. 2017). The respondent's task is to respond as quickly as possible to the items on a four-point Likert-type scale ("definitely yes", "rather yes", "rather no", "definitely no"). Cronbach's alpha for the current study was 0.83 . 
[2] HFS is a multidimensional tool measuring dispositional forgiveness, consisting of 18 items - 9 positive and 9 negative regarding responses to negative situations, resulting from one's actions and those of other people and circumstances independent of human factors rated by respondents on a 7-point Likert-type scale (1 - almost always false,7 - almost always true) (Kaleta, Mróz, Guzewicz, 2016). Cronbach's alpha for the current study was 0.75 .

[3] SWLS scale refers to the cognitive assessment of life satisfaction (Juczyński, 2001). It consists of 5 items. Respondents use a 7-point Likert scale to indicate their agreement with the statements, thus assessing their level of life satisfaction (1- completely disagree, 7completely agree). Cronbach's alpha for the current study was 0.90 .

The study was conducted remotely via the Google Forms platform.

Statistical analyses were performed using IBM SPSS version 26 software with PROCESS (Hayes, 2017).

\section{Results}

First, Pearson's r- correlation coefficients were calculated for the study variables. The results are shown in Table 2:

Table 2. r-Pearson correlation coefficients for the variables under study

\begin{tabular}{|c|c|c|c|c|c|c|c|c|c|c|c|}
\hline & 1 & 2 & 3 & 4 & 5 & 6 & 7 & 8 & 9 & 10 & 11 \\
\hline 1. HFS & - & & & & & & & & & & \\
\hline 2. Self & $.641^{* *}$ & - & & & & & & & & & \\
\hline 3. Others & $.639^{* *}$ & $.530^{* *}$ & - & & & & & & & & \\
\hline 4. Situations & $.605^{\star *}$ & $.516^{* *}$ & $.553^{* *}$ & - & & & & & & & \\
\hline 5. Self & $.634^{* *}$ & .128 & .067 & .095 & - & & & & & & \\
\hline 6. Others & $.714^{* *}$ & $.231^{*}$ & $.263^{* *}$ & .139 & $.658^{* *}$ & - & & & & & \\
\hline 7. Situations & $.707^{* *}$ & $.229^{*}$ & .183 & .172 & $.587^{\star *}$ & $.527^{* *}$ & - & & & & \\
\hline 8. SWLS & $.433^{* *}$ & $.235^{*}$ & $.329^{* *}$ & $.268^{* *}$ & $.269^{* *}$ & $.200^{*}$ & $.421^{* *}$ & - & & & \\
\hline 9. Empathy & $.304^{* *}$ & .183 & $.325^{* *}$ & $.430^{* *}$ & .087 & .065 & .103 & .174 & - & & \\
\hline $\begin{array}{l}\text { 10.Ammount } \\
\text { of donated } \\
\text { blood }\end{array}$ & .159 & -.023 & -.003 & .043 & .165 & .182 & $.242^{*}$ & $.256^{* *}$ & -.056 & - & \\
\hline $\begin{array}{l}\text { 11. Intership } \\
\text { in donating } \\
\text { blood }\end{array}$ & $.229^{*}$ & -.042 & -.019 & .101 &, $263^{* *}$ & $.214^{*}$ & $.292^{* *}$ & $.275^{* *}$ & .034 & $.638^{* *}$ & - \\
\hline
\end{tabular}


The correlation results showed statistically significant relationships between the general disposition to forgive and all of its components, as well as life satisfaction, the empathy quotient, and term of blood donation. Term of donation also showed a statistically significant correlations with life satisfaction and negative components of forgiveness. Life satisfaction displayed a significant correlation with all components of forgiveness. As regards the empathy quotient, the analysis only confirmed the relationship with general forgiveness and with positive disposition to forgive others and situations.

The next step involved a linear regression analysis in order to explain how life satisfaction and forgiveness explain empathy. The results are shown in Table 3:

Table 3. Linear regression analysis for empathy quotient, life satisfaction and disposition to forgive as predictors

\begin{tabular}{|c|c|c|c|c|c|c|c|c|}
\hline \multicolumn{2}{|c|}{ Step/Model } & B & SE & $\beta$ & $\mathbf{t}$ & p & $R^{2}$ & $\Delta R^{2}$ \\
\hline 11 & Gender & -3.241 & 1.580 & -.194 & -2.052 & .043 & \multirow[b]{2}{*}{.040} & \multirow[b]{2}{*}{.022} \\
\hline & Age & .049 & .087 & .053 & .567 & .572 & & \\
\hline \multirow{3}{*}{$\begin{array}{l}2 \\
2\end{array}$} & Gender & -3.438 & 1.563 & -.205 & -2.199 & .030 & \multirow{3}{*}{.072} & \multirow{3}{*}{.046 } \\
\hline & Age & -.014 & .092 & -.015 & -.148 & .883 & & \\
\hline & SWLS & .223 & .116 & . 193 & 1.933 & .056 & & \\
\hline \multirow[t]{2}{*}{3} & Gender & -3.696 & 1.507 & -.221 & -2.452 & .016 & \multirow{4}{*}{148} & \multirow{4}{*}{.116} \\
\hline & Age & -.078 & .091 & -.085 & -.863 & .390 & & \\
\hline \multirow[t]{2}{*}{3} & SWLS & .096 & .119 & .083 & .805 & .423 & & \\
\hline & HFS & .150 & .049 & .315 & 3.072 & .003 & & \\
\hline
\end{tabular}

Source: author's own study

In order to check how the dependent variable is explained by predictors, a stepwise method was used. In the first step, age and gender were entered, explaining empathy in $2 \%$; in the second step, the SWLS score was entered, showing that life satisfaction together with age and gender explains empathy in $4 \%$; in the third step, the total HFS score was entered, which, compared to step two, increased the percentage of explaining the variance to $11 \%$.

The next step was linear regression analysis for the empathy quotient, using two dimensions of forgiveness as predictors - reduced unforgiveness ( $\mathrm{N}$ scale) and positive forgiveness (P scale); the results are shown in Table 4:

Table 4. Regression analysis for empathy quotient with differentiated predictors- positive and reduced unforgiveness

\begin{tabular}{|c|c|c|c|c|c|c|c|c|}
\hline \multicolumn{2}{|c|}{ Model } & B & SE & $\beta$ & $\mathbf{t}$ & $\mathbf{p}$ & $R^{2}$ & $\Delta R^{2}$ \\
\hline $\mathbf{1}$ & P-SCALE & .307 & .071 & .383 & 4.326 & .000 & .147 & .139 \\
\hline $\mathbf{2}$ & N-SCALE & .068 & .065 & .101 & 1.060 & .292 & .010 & .001 \\
\hline
\end{tabular}


Source: author's own study

Regression analysis using the positive and negative dimension of forgiveness revealed that positive forgiveness had a greater, statistically significant role in explaining empathy, explaining $14 \%$ of the variance.

In the next step, mediation analysis using the PROCESS macro (Hayes, 2018) was conducted to check whether the general disposition to forgive plays a mediating role in explaining the empathy quotient by life satisfaction; for this purpose, model no. 4 was selected:

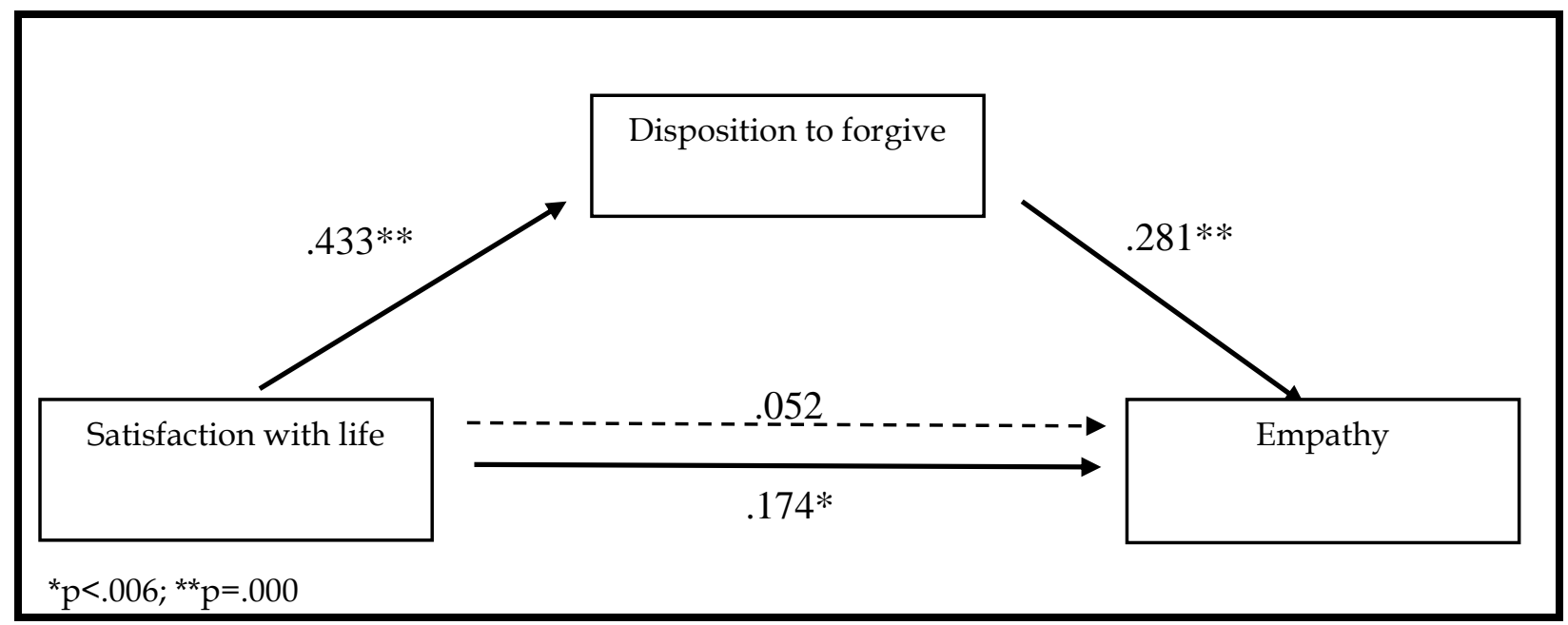

Fig.1. A simple mediation model (4) of the effect of life satisfaction on the empathy quotient involving the mediating role of the disposition to forgive.

Source: author's own study

The model used to explain the outcome variable with the independent variable is statistically significant, $\mathrm{F}(2,108)=5.632 ; \mathrm{p}<0.005$ and explains $9 \%$ of the variance. The results indicate that life satisfaction enhances the disposition to forgive (path a- $\mathrm{B}=.43$; $\mathrm{t}=5.018$, $95 \% \mathrm{CI}[.636 ; 1.467], \mathrm{p}=0.000$ ), and the disposition to forgive enhances empathy (path $\mathrm{b}$ $\mathrm{B}=.28, \mathrm{t}=2.768, \mathrm{p}=0.006,95 \% \mathrm{C}[\mathrm{I} 0.038 ; 0.230])$. Multiple mediation analyses showed that the total indirect effect of life satisfaction on empathy via forgiveness was significant 0.141 (95\% CI [0.032; 0.273]). The total effect of life satisfaction of forgiveness $B=.17 p<0.06$ (statistical trend) was reduced to nonsignificant with the inclusion of the mediator (the direct effect $B=.05, p=.61$ ).

Next, gender differences in relation to study variables were analyzed, however the analysis using non-parametric tests failed to reveal any significant differences between women and men.

\section{Discussion}


The aim of the present study was to examine the relationship between life satisfaction, forgiveness and the empathy quotient, the degree to which life satisfaction and forgiveness can explain empathy and the mediating role of forgiveness between life satisfaction and empathy. In addition, the study was intended to check whether there is any relationship between the term of blood donation and volume of donated blood, and the level of life satisfaction and the empathy quotient.

The findings partially confirmed hypothesis H1, showing statistically significant and positive relationships between all factors of (positive and negative) forgiveness with the level of life satisfaction and the general forgiveness with the empathy quotient. Moreover, the highest correlation coefficients of forgiveness and life satisfaction, apart from the general forgiveness, were found for positive forgiveness of others (strangers) and negative forgiveness of situations. This result is confirmed by the study of Kaleta and Mróz (2018), which found a relationship between forgiveness and life satisfaction, and the key role that forgiveness plays in explaining life satisfaction (Kaleta, Mróz, 2018). Based on the justification given, hypothesis $\mathrm{H} 1 \mathrm{~b}$ can also be considered confirmed. As regards hypothesis H1a, no statistically significant correlation was found between life satisfaction and level of empathy. Conclusions drawn from the obtained results may indicate that the respondents may show greater forbearance and understanding for others, which was confirmed by the correlation between general forgiveness, positive forgiveness of others and of situations, which may in a way confirm findings obtained in the study by Farrow et al. (2000) and serve as the starting point for further neuropsychology research (Farrow et al., 2000). Another study by Davis and Gold (2011) showed a strong correlation between forgiveness and empathy, which may suggest that the readiness to forgive transgressions may result from empathic motives and, on the other hand, empathy itself may be strengthened by forgiveness.

In the case of hypothesis $\mathrm{H} 2$, it has been shown that the level of disposition to forgive together with perceived life satisfaction jointly explain empathy, which may serve as confirmation of the hypothesis. This relationship is substantiated by the previously cited findings of Ye et al. (2019), which showed strong relationships between empathy, forgiveness and perceived life satisfaction (Ye et al. 2019). In the case of hypothesis H2a, it can also be considered confirmed - regression analyses conducted separately for the positive and negative dimensions of forgiveness, showed that positive forgiveness explains the level of empathy to a significantly greater extent.

For hypothesis $\mathrm{H} 3$, mediation analysis revealed that the disposition to forgive plays a mediating role in the relationship between life satisfaction and empathy. That means that forgiveness may significantly enhance life satisfaction, which may also be relevant to empathy levels. Confirmation of this relationship can be found in a study by Liu et al. (2013), 
which found that forgiveness has an important mediating role in the relationship of taking another's perspective and life satisfaction.

As regards hypothesis $\mathrm{H} 4$, no statistically significant gender differences were found for the study variables. This result is supported by the study of Aparicio et al. (2019), which showed no gender differences the level of empathy. As regards forgiveness, our results were also confirmed in the study by Otalvaro et al. (2017), which although showed a greater tendency among women to forgive themselves than among men to forgive others, however failed to reveal a statistically significant difference between the two groups (Otalvaro et al. 2017). As regards life satisfaction, absence of differences between women and men can be partially supported in a study by Joshanloo (2018), which included a group of 952,739 people representing 150 countries, and indicated only small gender differences in this respect (Joshanloo, 2018).

Hypothesis H5 was partially confirmed. The results showed statistically significant relationships between the term of blood donation and overall forgiveness, all factors of negative forgiveness and level of life satisfaction. This relationship may mean that the longterm nature of donations extended over an increasing number of years may enhance life satisfaction through the awareness of helping others, and it may be considered as another hypothesis for a longitudinal study.

The results also suggest that forgiveness and life satisfaction, which may increase along with subsequent regular donations, may enhance empathy among blood donors.

\section{Limitations}

The presented study had its limitations and shortcomings. The main shortcoming may have been a small sample and an uneven gender ratio within the sample. Another important limitation was the way the study was conducted - remotely, and the way the study participants were recruited - through membership in honorary blood donor groups in social media. Another shortcoming may also have been the tool used to measure the level of empathy; future research could use multidimensional tools that take into account other levels of empathy.

The limitations however, do not necessarily interfere with the interpretation and implications of the study and the results obtained, which may serve as the starting point for further research in voluntary blood donors. Future research could include, for example, longitudinal studies to investigate the relationship between longer-term blood donation and life satisfaction indicated in the results of this study. Other research proposals could also include measuring health behaviors in a group of blood donors in relation, for example, to life satisfaction or altruism. Comparative studies in the above-mentioned areas between 
blood donors and non-donors may also prove interesting. It might also be interesting to investigate the levels and types of motivation involved in becoming a blood donor.

Voluntary blood donors appear to be a particularly interesting group to researchers as the decision to donate blood and to regularly undergo the donation process seems to be a psychologically interesting initiative. Further research in this group of respondents may provide many useful implications and ideas for institutions promoting such activities, which, may contribute to the increase in the number of voluntary blood donors and consequently to a greater blood supply for medical purposes.

\section{Bibliography:}

Alfieri, S. (2017). Representations and motivations of blood donation in adolescence through a mixed method approach, Transfusion and Apheresis Science, 56 (5), 723-731, https:// doi.org/10.1016/j.transci.2017.08.023.

Amponsah-Afuwape, S.A., Myers, L.B., Newman, S.P.(2002). Cognitive predictors of ethnic minorities' blood donation intention, Psychology, Health \& Medicine, 7, 357-361.

Aparicio, D.E., Ramos, A.E., Mendoza, J., Utsman-Abarca, R., Calzadilla-Núñez, A., \& DíazNarváez, V.P. (2019). Levels of empathy, empathy decline and differences between genders in medical students of Cartagena (Colombia), Educación Médica, 20, 136-143, https:// doi.org/10.1016/j.edumed.2018.06.004.

Brudek, P., Steuden, S. (2015). Polska adaptacja Skali Przebaczenia Małżeńskiego (MOFS) FG Paleari, FD Finchama, C. Regalii, Family Forum, 5, 161-179.

Chung, Myung-Sun (2014). "Pathways between attachment and marital satisfaction: The mediating roles of rumination, empathy, and forgiveness, Personality and Individual Differences, 70, 246-251.

Czapiński, J. (red.), (2004). Psychologia pozytywna, nauka o szczęściu, zdrowiu, sile i cnotach człowieka, Warszawa: Wydawnictwo Naukowe PWN.

Davis, M.H. (1999). Empatia. O umiejętności wspótodczuwania, Gdańsk: GWP.

Davis, M.H., Mitchell, K.V., Hall, J. A. Lothert, J., Snapp,T., Meyer, M. (1999). Empathy, expectations, and situational preferences: Personality influences on the decision to participate in volunteer helping behaviors, Journal of Personality, 67, 469-501.

Davis, J.R., Gold, G.J. (2011). An examination of emotional empathy, attributions of stability, and the link between perceived remorse and forgiveness, Personality and Individual Differences, 50, 392-397.

Diener, E., Emmons, R.A., Larsen, R.J., \& Griffin, S. (1985). The Satisfaction with Life Scale, Journal of Personality Assessment, 49, 71-75.

Di Tella, Marialaura, et al. (2020). Professional quality of life and burnout among medical physicists working in radiation oncology: The role of alexithymia and empathy, Physics and Imaging in Radiation Oncology, 15, 38-43. 
Docety, J., Moriguchi, Y. (2007), The empathic brain and its dysfunction in psychiatric populations: implications fort intervention across different clinical conditions, BioPsychoSocial Medicine, 1, 1-22.

Exline, J.J., Worthington, E. L., Hill, P., McCullough, M. E. (2003). Forgiveness and Justice: A Research Agenda for Social and Personality Psychology, Personality and Social Psychology Review, 7, 337-348.

Farrow, T.F.D., Wilkinson, I.D., Zheng, Y., Tarrier, N., Griffiths, P.D., Deakin, J.F. W., \& Woodruff, P.W.R. (2000). Theory of mind, empathy and forgiveness - a functional MRI study, NeuroImage, 5 (11), S58.

Fincham, F.D., Hall, J.H., \& Beach, S.R. (2007). Til Lack of Forgiveness Doth Us Part: Forgiveness and Marriage, (in:) Handbook of forgiveness, 231-250, Routledge.

Giles, M., McClenahan, C., Cairns, E., et al. (2004). An application of the theory of planned behaviour to blood donation: The importance of self-efficacy, Health Education Research, 19, 380-391.

Goette, L., \& Stutzer, A. (2020). Blood donations and incentives: Evidence from a field experiment, Journal of Economic Behavior \& Organization, 170, 52-74.

Gottman, J.M. (2014). What predicts divorce? The relationship between marital processes and marital outcomes, New York \& London: Psychology Press.

Hayes, A.F. (2017). Introduction to mediation, moderation, and conditional process analysis: A regression-based approach, Guilford Publications.

Higgins, C. (1994). Blood transfusion: risks and benefits, British Journal of Nursing, 3 (19), 986991.

Jankowiak-Siuda, K., Kantor-Martynuska, J., Siwy-Hudowska, A., Śmieja, M., DobrołowiczKonkol, M., Zaraś-Wieczorek, I., Siedler, A. (2017). Analiza właściwości psychometrycznych polskiej wersji językowej Skróconej Skali Ilorazu Empatii (SSIE)The Empathy Quotient (EQ-Short), Psychiatria Polska, 51, 719-734, https:// doi.org/10.12740/PP/64270.

Joshanloo, M. (2018). Gender differences in the predictors of life satisfaction across 150 nations, Personality and Individual Differences, 135, 312-315, https:// doi.org/10.1016/j.paid.2018.07.043.

Juczyński, Z. (2001). Narzędzia pomiaru w promocji i psychologii zdrowia. Skala Satysfakcji z Życia, 134-138, Warszawa: Pracownia Testów Psychologicznych Polskiego Towarzystwa Psychologicznego.

Kaleta, K., Mróz, J., Guzewicz, M. (2016). Polska adaptacja Skali Przebaczenia - Heartland Forgiveness Scale, Przeglad Psychologiczny, 59, 401-416.

Kaleta, K., \& Mróz, J. (2018). Forgiveness and life satisfaction across different age groups in adults, Personality and Individual Differences, 120, 17-23, https:// doi.org/10.1016/j.paid.2017.08.008. 
Kaźmierczak, M. (2004). Empatia w strukturach organizacyjnych, Roczniki Psychologiczne, 2, 131-144.

Kazimierczak, M. (2008). Oblicza empatii w relacjach matżeńskich: perspektywa psychologiczna,Gdańsk: Wydawnictwo Uniwersytetu Gdańskiego.

Liu, Y., Zhou, M., Wang, L., Xiaoshan, L., \& Zhang, J. (2013). Effect of empathy, forgiveness on urban residents' life satisfaction, Chinese Journal of Behavioral Medicine and Brain Science, 22 (7), 633-635.

McCullough M.E., Worthington Jr E.L., (1999). Religion and the forgiving personality, Journal of Personality, 6, 1141-1164.

McCullough M.E., Pargament K.I., Thoresen C.E. (2000). The psychology of forgiveness: History, conceptual issues, and overview, (in:) M.E. McCullough, K.I. Parga-ment, C.E. Thoresen (eds.), Forgiveness: Theory research and practice, 1-14, New York.

Mróz, J., Kaleta, K. (2016). Pomiar przebaczenia sytuacyjnego w świetle najważniejszych metod kwestionariuszowych, Polskie Forum Psychologiczne, 21 (2), 255-271.

Otalvaro, A.R., Munoz, M., Uribe, A., Katia, C., \& Maria, R. (2017). Forgiveness and armed conflict in a Colombian Caribbean region: Differences between genders, European Psychiatry, 41(S1), 731-731.

Pastwa-Wojciechowska, B., Piechowicz, M., \& Bidzan, M. (2015). Satysfakcja z życia a empatia i poczucie umiejscowienia kontroli bezdomnych kobiet. Doniesienie wstępne, Polskie Forum Psychologiczne, 20 (1), 16-30.

Rembowski, J. (1989). Empatia, Warszawa: PWN.

Reykowski, J. (1992). Procesy emocjonalne, motywacja, osobowość, Warszawa: PWN.

Sells, J.N., Hargrave, T.D. (1998). Forgiveness: A review of the theoretical and empirical literature, Journal of Family Therapy, 20 (1), 21-36.

Slonim, R., Wang, C., Garbarino, E. (2014). The market for blood, Journal of Economic Perspectives, 28 (2), 177-196.

Thompson L.Y., Snyder C.R. (2003). Measuring forgiveness, (in:) S.J. Lopez, C.R. Snyder (eds.), Positive psychological assessment: A handbook of models and measures, 301-312, Washington.

Thompson, L.Y., Snyder, C.R., Hoffman, L., Michael, S.T., Rasmussen, H.N., Billings, L.S., Heinze, L., Neufeld, J.E., Shorey, H.S., Roberts, J.C., Roberts, D.E. (2005). Dispositional forgiveness of self, others, and situations, Journal of Personality, 73 (2), 313-359.

Titmuss, R. (1971). The gift relationship: From human blood to social policy, New York: Vintage.

Too, A., Gatien, C., \& Cormier, S. (2021). Treatment satisfaction mediates the association between perceived physician empathy and psychological distress in a community sample of individuals with chronic pain, Patient Education and Counseling, 104 (5), 1213-1221. 
Wakabayashi, A., Baron-Cohen, S., Wheelwrigh,t S., Goldenfeld, N., Delaney, J., Fine, D. et al. (2006). Development of short forms of the Empathy Quotient (EQ) and the Systemizing Quotient (SQ), Personality and Individual Differences, 41, 929-940.

Wołpiuk-Ochocińska, A. (2018). Kompetencje społeczne i poczucie własnej skuteczności jako predyktory poczucia szczęścia u nauczycieli, Edukacja - Technika - Informatyka, 4 (26), 372-378.

Wysokiński, M., Fidecki, W., Walas, L., Ślusarz, R., Sienkiewicz, Z., Sadurska, A., \& Kachaniuk, H. (2009). Satysfakcja z życia polskich pielęgniarek, Problemy Pielegniarstwa, 17 (3), 167-172.

Ye, Y., Ma, D., Yuan, H., Chen, L., Wang, G., Shi, J., \& Jiang, X. (2019). Moderating effects of forgiveness on relationship between empathy and health-related quality of life in hemodialysis patients: a structural equation modeling approach, Journal of Pain and Symptom Management, 57 (2), 224-232.

Zarzycka, B. (2016). Psychological Concepts of Forgiveness in Interpersonal Relations, Paedagogia Christiana, 37 (1), 163-181, http:/ / dx.doi.org/10.12775/PCh.2016.009.

Zimbardo, P., Johnson L.R., McCann, V. (2017). Psychologia kluczowe koncepcje. Tom 5, Człowiek i jego środowisko, Warszawa: Wydawnictwo Naukowe PWN.

\section{Netography:}

Przelicznik donacji krwi i składników krwi, witryna RCKiK Wrocław: https://www.rckik.wroclaw.pl/kalkulator.php (access: 01.07.2021). 